\title{
A COMPARATIVE CLINICAL STUDY TO EVALUATE THE EFFICACY OF LEVOBUPIVACAINE WITH CLONIDINE AND LEVOBUPIVACAINE WITH DEXMEDETOMIDINE IN SUPRACLAVICULAR BRACHIAL PLEXUS BLOCK
}

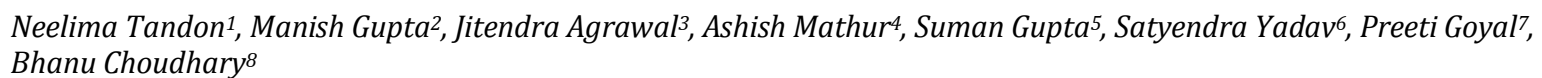

${ }_{1}^{1}$ Associate Professor, Department of Anaesthesia, G. R. Medical College, Gwalior, Madhya Pradesh.

${ }^{2}$ Former Post Graduate Student, Department of Anaesthesia, G. R. Medical College, Gwalior, Madhya Pradesh.

${ }^{3}$ Assistant Professor, Department of Anaesthesia, G. R. Medical College, Gwalior, Madhya Pradesh.

${ }^{4}$ Assistant Professor, Department of Anaesthesia, G. R. Medical College, Gwalior, Madhya Pradesh.

${ }^{5}$ Assistant Professor, Department of Anaesthesia, G. R. Medical College, Gwalior, Madhya Pradesh.

${ }^{6}$ Assistant Professor, Department of Anaesthesia, G. R. Medical College, Gwalior, Madhya Pradesh.

${ }^{7}$ Associate Professor, Department of Anaesthesia, G. R. Medical College, Gwalior, Madhya Pradesh.

${ }^{8}$ Professor and HOD, Department of Anaesthesia, G. R. Medical College, Gwalior, Madhya Pradesh.

\section{ABSTRACT}

\section{OBJECTIVE}

The objective of this study is to compare clonidine and dexmedetomidine as an adjuvant to levobupivacaine in supraclavicular brachial plexus block with respect to onset, duration of sensory and motor block and duration of analgesia.

\section{MATERIALS AND METHODS}

A total of 90 ASA grade I and II patients of either sex, aged 18-60 yrs. scheduled for elective upper limb surgeries under supraclavicular brachial plexus block were divided into 3 equal groups in a randomized fashion. Group L ( $\mathrm{n}=30$ ) received $1 \mathrm{~mL}$ NS, group LC $(=30)$ received $1 \mathrm{~mL}(150 \mathrm{~g})$ clonidine and group $\mathrm{LD}(\mathrm{n}=30)$ received $1 \mathrm{~mL}(100 \mathrm{~g})$ dexmedetomidine added to $30 \mathrm{~mL}$ of $0.5 \%$ levobupivacaine. Onset and recovery time of sensory and motor block, duration of analgesia and quality of block were studied in all three groups.

\section{RESULTS}

Onset time of sensory and motor blockade was $12.43 \pm 2.56 \mathrm{~min}$ and $17.96 \pm 3.05 \mathrm{~min}$ respectively in group L, $9.03 \pm 1.60 \mathrm{~min}$ and $15.00 \pm 2.40 \mathrm{~min}$ respectively in group LC and $8.13 \pm 2.51 \mathrm{~min}$ and $12.13 \pm 2.89 \mathrm{~min}$ respectively in group LD. Duration of sensory and motor blockade was $660.16 \pm 44.28 \mathrm{~min}$ and $535.33 \pm 50.66 \mathrm{~min}$ respectively in group L, $880.16 \pm 55.48 \mathrm{~min}$ and $771.83 \pm 54.19 \mathrm{~min}$ respectively in group LC and $930.66 \pm 48.02 \mathrm{~min}$ and $811.83 \pm 52.08 \mathrm{~min}$ respectively in group LD. Time of rescue analgesia was $728.86 \pm 45.12 \mathrm{~min}$ in group L, $1013.5 \pm 59.01 \mathrm{~min}$ in group LC and $1159.8 \pm 56.8 \mathrm{~min}$ in group LD ( $<<0.05)$.

\section{CONCLUSION}

Dexmedetomidine when added to LA in supraclavicular brachial plexus block prolongs the duration of sensory and motor blockade and also the time for rescue analgesia as compared to clonidine. Dexmedetomidine also enhances quality of block $(\mathrm{LD}>\mathrm{LC}>\mathrm{C})$.

\section{KEYWORDS}

Supraclavicular Brachial Plexus Block, Levobupivacaine, Clonidine, Dexmedetomidine.

HOW TO CITE THIS ARTICLE: Tandon N, Gupta M, Agrawal J, et al. A comparative clinical study to evaluate the efficacy of levobupivacaine with clonidine and levobupivacaine with dexmedetomidine in supraclavicular brachial plexus block. J. Evolution Med. Dent. Sci. 2016;5(19):925-929, DOI: 10.14260/jemds/2016/215

\section{INTRODUCTION}

Peripheral nerve blocks are gaining wide popularity in anaesthesia clinical practice and can be used in variety of surgical procedures, for surgical anaesthesia and postoperative pain. Supraclavicular approach gives the most effective block for upper extremity and is carried out at the level of trunks of brachial plexus. ${ }^{1}$ the plexus is blocked where it is most compact. ${ }^{2}$ i.e. at the middle of brachial plexus, resulting in homogeneous spread of anaesthetic throughout the plexus with a fast onset and complete block. ${ }^{3}$

Financial or Other, Competing Interest: None.

Submission 22-01-2016, Peer Review 18-02-2016,

Acceptance 23-02-2016, Published 04-03-2016.

Corresponding Author:

Dr. Neelima Tandon,

Flat-304, Phase 3, Garden Homes,

City Center Gwalior,

Madhya Pradesh.

E-mail: dr.neelimatandon21@gmail.com

DOI: $10.14260 /$ jemds/2016/215
The racemic mixture of bupivacaine resulted in cardiac and central nervous system toxic effects in some patients. ${ }^{4,5}$ which were attributed to the dextrobupivacaine enantiomer. ${ }^{6}$ Levobupivacaine is the $S(-)$ enantiomer of racemic bupivacaine. It has less cardiotoxicity compared with bupivacaine. ${ }^{7}$ and its pharmacology and duration of anaesthesia are similar to those of bupivacaine. ${ }^{7}$

Clonidine, $\alpha_{2}$ receptor agonist, an imidazoline derivative is highly lipid soluble, acting on both spinal and supraspinal level within central nervous system and has been used as centrally acting antihypertensive agent. It has been used for many years as an additive to local anaesthetic. ${ }^{8,9}$ Clonidine provides approximately 100 additional minutes of analgesia with long-acting local anaesthetic. ${ }^{8}$ Most studies used between 100-150 $\mu$ g with higher dose showing side effects including sedation, bradycardia and hypotension. ${ }^{8}$

Dexmedetomidine is a highly selective $\alpha_{2}$ adrenoceptor agonist that has been shown to have both sedative and analgesic effects. ${ }^{10,11}$ compared with clonidine, 
dexmedetomidine has an $\alpha_{2}: \alpha_{1}$ adrenoceptor ratio of approximately 1600:1 (Seven to eight times higher than clonidine).12 Dexmedetomidine was first proposed as an adjuvant capable of prolonging duration of sensory and motor block produced by nerve block by Memis and Colleagues. ${ }^{13}$ Dexmedetomidine has shown to prolong the duration of block and postoperative analgesia when added to local anaesthetic in various regional blocks. ${ }^{13-16}$

In this study, we compare the onset and degree of sensory and motor blockade of levobupivacaine with clonidine and dexmedetomidine in supraclavicular brachial plexus block.

\section{MATERIALS AND METHODS}

After ethical committee approval and written informed consent, this double blind randomized, prospective clinical study was carried out in 90 patients of ASA grade I and II of either sex, aged 18-60 yrs. scheduled for upper limb surgeries. Patients with known history of bleeding disorders, peripheral neuropathies allergy or sensitivity or any other reaction to local anaesthetic of amide type, receiving treatment with $\alpha$ adrenergic agonists/antagonists, those with a history of cardiac, respiratory, hepatic or renal failure; and pregnant women were excluded from the study.

Ninety patients who fulfilled the eligibility criteria were chosen, explained about the procedure and written consent was taken. Patients were subsequently randomized into three groups of 30 each.

1. Group L $(\mathrm{n}=30)$ : $30 \mathrm{~mL}$ of $0.5 \%$ Levobupivacaine with $1 \mathrm{~mL}$ normal saline. (Control)

2. Group LC ( $\mathrm{n}=30): 30 \mathrm{~mL}$ of $0.5 \%$ Levobupivacaine with $150 \mathrm{mcg}$ Clonidine $(1 \mathrm{~mL})$.

3. Group LD $(\mathrm{n}=30)$ : $30 \mathrm{~mL}$ of $0.5 \%$ Levobupivacaine with $100 \mathrm{mcg}$ Dexmedetomidine $(1 \mathrm{~mL})$.

After securing an intravenous access with 18-G cannula, RL solution was started. Heart rate (HR), Systolic blood pressure (SBP), Diastolic blood pressure, respiratory rate (RR) and oxygen saturation (SPO2) were recorded with multiparameter monitor (Beneview T5, Mindray China) Supraclavicular brachial plexus block was performed under all aseptic precautions and after local infiltration of $2 \%$ Lidocaine $2 \mathrm{~mL}$, neural localization was achieved using a nerve stimulator connected to a 22 -gauge, $50 \mathrm{~mm}$ long stimulating needle. The location end point was a distal motor response, that is the movement of the fingers and the thumb with an output current of $0.5 \mathrm{~mA}$.

Onset of sensory block is defined as the time elapsed between injection of drug and complete loss of sensation as analysed by pinprick test using a 3 -point scale: $0=$ normal sensation, $1=$ loss of sensation of pinprick, $2=$ loss of sensation of touch. Duration of sensory block was defined as the time elapsed between injection of the drug and the complete resolution of anaesthesia on all nerves.

Onset of motor block was defined as the time elapsed from injection of drug to complete motor block. Motor block was evaluated by thumb abduction (Radial nerve), thumb adduction (Ulnar nerve), thumb opposition (Median nerve), and flexion of the elbow in supination and pronation of the forearm (Musculocutaneous nerve). Measurements were performed using a modification of the Lovett rating scale. ${ }^{17}$ Grade 6: Normal muscular force.
Grade 5: Slightly reduced muscular force.

Grade 4: Pronounced reduction of muscular force.

Grade 3: Slightly impaired mobility.

Grade 2: Pronounced mobility impairment.

Grade 1: Almost complete paralysis.

Grade 0: Complete paralysis.

Assessment was done at every $1 \mathrm{~min}$ interval from the time of injection of test drug until the block was established. Only patient with complete motor block (Grade 0) were included in study and equal number of new cases were added to complete the study. Duration of motor block was defined as time elapsed between injections of the drug to complete return of motor power (Grade 6).

Postoperative pain was assessed using a visual analogue score scale which consisted of a $10 \mathrm{~cm}$ horizontal scale with gradations marked as ' 0 ' means no pain at all and ' 10 ' means unbearable pain. VAS score was recorded every $30 \mathrm{~min}$ in the postoperative period till the conclusion of study.

Sedation was assessed on the basis of Chernik sedation score. 18

0 - Completely awake.

1 - Sleeping but responding to verbal command.

2 - Deep sleep but arousable.

3 - Deep sleep not arousable.

Any complications such as nausea, vomiting, bradycardia (HR<50 beats per minute), hypotension (A 20\% decrease in relation to the baseline value), haematoma, headache, convulsions, respiratory distress and hypoxemia (Spo $2<90 \%)$ if occurred were recorded and treated appropriately.

Pulse rate (PR), systolic blood pressure (SBP), diastolic blood pressure (DBP), oxygen saturation $\left(\mathrm{SpO}_{2}\right)$, respiratory rate (RR), 3-lead ECG monitoring was done continuously by multi-parameter monitor (Mindray Beneview T5) throughout the operative procedure. Recording of parameters were noted at $0,5,10,15,20$ and at $30 \mathrm{~min}$ interval up to $90 \mathrm{~min}$ and then every hour till $750 \mathrm{~min}$.

The observations recorded in all groups were tabulated and statistical analysis was carried out using SPSS V.17 software for windows. In the intergroup comparison an independent student ' $\mathrm{t}$ ' test was used. For intragroup comparisons unidirectional repetitive variance analysis was used. Statistical significance was accepted as not significant and significant at $\mathrm{P}>0.05$ and $\mathrm{P}<0.05$ respectively.

\section{RESULTS}

All three groups were comparable in terms of age, weight and gender. (Table 1) $(p>0.05)$ : There was even distribution of age, weight and sex in all the three groups. The mean $( \pm \mathrm{SD})$ age of patients in group L, LC and LD were $37.96 \pm 14.79$ yrs., $40.63 \pm 12.94$ yrs. and $36.63 \pm 12.70$ yrs. respectively. The mean $( \pm \mathrm{SD})$ weight of group L, LC and LD were $66.30 \pm 8.85 \mathrm{~kg}$, $63.40 \pm 9.01 \mathrm{~kg}$ and $63.10 \pm 4.28 \mathrm{~kg}$ respectively. Out of 90 patients, 64 patients $(71.11 \%)$ were male as compared to 26 female patients (28.89\%). The randomly selected group were comparable for the weight parameters (Statistically insignificant ( $p>0.05)$ ). 


\begin{tabular}{|c|c|c|c|c|c|c|c|}
\hline \multirow{2}{*}{ Sl. No. } & \multirow{2}{*}{ Parameters } & \multicolumn{2}{|c|}{ Group L } & \multicolumn{2}{c|}{ Group LC } & \multicolumn{2}{c|}{ Group LD } \\
\cline { 3 - 8 } & & Mean & $\mathbf{\pm S D}$ & Mean & $\mathbf{\pm S D}$ & Mean & $\mathbf{\pm}$ \\
\hline 1. & Age (yrs.) & 37.96 & 14.79 & 40.63 & 12.94 & 36.63 & 12.70 \\
\hline 2. & Weight (kgs) & 66.30 & 8.85 & 63.40 & 9.01 & 63.10 & 4.28 \\
\hline 3. & Sex (M:F) & \multicolumn{2}{|c|}{$21: 9$} \\
\hline
\end{tabular}

Table showing demographic profile of patients in three groups according to age, weight and sex.

\section{Sensory Blockade}

The onset time of sensory blockade (mean \pm SD), which was $12.43 \pm 2.56 \mathrm{~min}$ in Group L, 9.03 $\pm 1.60 \mathrm{~min}$ in Group LC and $8.13 \pm 2.51 \mathrm{~min}$ in Group LD. The onset of sensory blockade was found to be faster in both group LC and group LD as compared to group $\mathrm{L}$ and the difference was statistically significant ( $p$ $<0.05$ ), whereas onset of sensory blockade was rapid in group LD as compared to group LC, but the difference was statistically insignificant $(p>0.05)$. Mean $( \pm S D)$ of sensory blockade duration was $660.16 \pm 44.28 \mathrm{~min}$ in Group L, 880.16 $\pm 55.48 \mathrm{~min}$ in Group LC and 930.66 $\pm 48.02 \mathrm{~min}$ in Group LD. Sensory blockade duration is significantly prolonged in both Groups LC and LD as compared to Group L. Duration of sensory blockade in Group LD was also significantly prolonged as compared to Group LC. (Table 2 \& 3 )

\begin{tabular}{|c|c|c|c|c|c|c|}
\hline \multirow{2}{*}{$\begin{array}{c}\text { Para } \\
\text { meters }\end{array}$} & \multicolumn{2}{|c|}{ Group L } & \multicolumn{2}{c|}{ Group LC } & \multicolumn{2}{c|}{ Group LD } \\
\cline { 2 - 7 } & Mean & \pm SD & Mean & \pm ISD & Mean & 士SD \\
\hline $\begin{array}{c}\text { Onset time } \\
\text { of sensory } \\
\text { blockade } \\
\text { (min) }\end{array}$ & 12.43 & 2.56 & 9.03 & 1.60 & 8.13 & 2.51 \\
\hline $\begin{array}{c}\text { Duration } \\
\text { of Sensory } \\
\text { blockade } \\
\text { (min) }\end{array}$ & 660.16 & 44.28 & 880.16 & 55.48 & 930.66 & 48.02 \\
\hline
\end{tabular}

Table 2: Showing Comparison of Sensory Blockade (Min) in the Three Groups

\begin{tabular}{|c|c|c|c|c|c|c|c|}
\hline \multirow{2}{*}{$\begin{array}{l}\text { Sl. } \\
\text { No. }\end{array}$} & \multirow{2}{*}{ Groups } & \multicolumn{2}{|c|}{$\begin{array}{c}\text { Group } \\
\text { L vs. LC }\end{array}$} & \multicolumn{2}{|c|}{$\begin{array}{c}\text { Group } \\
\text { L vs. LD }\end{array}$} & \multicolumn{2}{|c|}{$\begin{array}{c}\text { Group } \\
\text { LC vs. LD }\end{array}$} \\
\hline & & $\begin{array}{c}\mathrm{t} \\
\text { value }\end{array}$ & $\begin{array}{c}\mathbf{p} \\
\text { value }\end{array}$ & $\begin{array}{c}\mathrm{t} \\
\text { value }\end{array}$ & $\begin{array}{c}\mathbf{p} \\
\text { value }\end{array}$ & $\begin{array}{c}\mathrm{t}- \\
\text { value }\end{array}$ & $\begin{array}{c}\mathbf{p} \\
\text { value }\end{array}$ \\
\hline 1 & $\begin{array}{c}\text { Onset } \\
\text { time of } \\
\text { sensory } \\
\text { blockade } \\
\text { (min) }\end{array}$ & 6.14 & $0.00 \$$ & 6.55 & $0.00 \$$ & 1.65 & $0.10 \#$ \\
\hline 2 & $\begin{array}{l}\text { Duration } \\
\text { of } \\
\text { sensory } \\
\text { blockade } \\
\text { (min) }\end{array}$ & 16.97 & $0.00 \$$ & 22.68 & $0.00 \$$ & 3.76 & $0.00 \$$ \\
\hline
\end{tabular}

\section{Motor Blockade}

Onset time (Mean \pm SD) of motor blockade was $17.96 \pm 3.05 \mathrm{~min}$, $15.00 \pm 2.40 \mathrm{~min}$ and $12.13 \pm 2.89 \mathrm{~min}$ in Group L, LC and LD respectively. Onset of motor blockade was found to be rapid in Group LD as compared to Group LC and Group L (LD>LC>L). These changes were statistically significant when compared to each other $(\mathrm{p}<0.05)$. Duration of motor blockade (mean \pm SD) was $535.33 \pm 50.66 \mathrm{~min}$ in Group L, 771.83 $\pm 54.19 \mathrm{~min}$ in Group LC and $811.83 \pm 52.08 \mathrm{~min}$ in Group LD. Duration of motor blockade was prolonged in both Groups LC and LD as compared to Group L. These changes were statistically significant when compared to each other $(\mathrm{p}<0.05)$. (Table 4 \& 5).

\begin{tabular}{|c|c|c|c|c|c|c|}
\hline \multirow{2}{*}{$\begin{array}{c}\text { Para } \\
\text { meters }\end{array}$} & \multicolumn{2}{|c|}{ Group L } & \multicolumn{2}{c|}{ Group LC } & \multicolumn{2}{c|}{ Group LD } \\
\cline { 2 - 7 } & Mean & \pm SD & Mean & \pm SD & Mean & ISD \\
\hline $\begin{array}{c}\text { Onset } \\
\text { time of } \\
\text { motor } \\
\text { blockade } \\
\text { (min) }\end{array}$ & 17.96 & 3.05 & 15.00 & 2.40 & 12.13 & 2.89 \\
\hline $\begin{array}{c}\text { Duration } \\
\text { of } \\
\text { blockade } \\
\text { (min) }\end{array}$ & 535.33 & 50.66 & 771.83 & 54.19 & 811.83 & 52.08 \\
\hline \multicolumn{6}{|c|}{ Table 4: Showing Comparison of } \\
\hline
\end{tabular}

\begin{tabular}{|c|c|c|c|c|c|c|}
\hline \multirow{2}{*}{ Parameters } & \multicolumn{2}{|c|}{$\begin{array}{c}\text { Group L vs. } \\
\text { LC }\end{array}$} & \multicolumn{2}{c|}{$\begin{array}{c}\text { Group L vs. } \\
\text { LD }\end{array}$} & \multicolumn{2}{c|}{ Group LC vs. LD } \\
\cline { 2 - 7 } & $\begin{array}{c}\mathbf{t} \\
\text { value }\end{array}$ & $\begin{array}{c}\mathbf{p} \\
\text { value }\end{array}$ & $\begin{array}{c}\mathbf{t} \\
\text { value }\end{array}$ & $\begin{array}{c}\mathbf{p} \\
\text { value }\end{array}$ & $\begin{array}{c}\mathbf{t} \\
\text { value }\end{array}$ & p value \\
\hline $\begin{array}{c}\text { Onset time } \\
\text { of motor } \\
\text { blockade } \\
\text { (min) }\end{array}$ & 4.17 & $0.00 \$$ & 0.828 & $0.00 \$$ & 4.168 & $0.00 \$$ \\
\hline $\begin{array}{c}\text { Duration of } \\
\text { blockade } \\
\text { (min) }\end{array}$ & 17.46 & $0.00 \$$ & 0.995 & $0.00 \$$ & 2.915 & $0.00 \$$ \\
\hline \multicolumn{4}{|c|}{ Table 5: Showing Intergroup Statistical } \\
\multicolumn{6}{|c|}{ Comparison of Motor Blockade among Three Groups } \\
\hline
\end{tabular}

\section{Time of Rescue Analgesia}

Time of rescue analgesia was $728.86 \pm 45.12 \mathrm{~min}$ in Group L, 1013.5 $\pm 59.01 \mathrm{~min}$ in Group LC and 1159.8 $\pm 56.8 \mathrm{~min}$ in Group LD. The time of rescue analgesia as assessed by VAS score was prolonged in Group LD as compared to other Groups ( $L D>L C>L$ ). On intergroup comparison these changes were found to be statistically significant $(\mathrm{p}<0.05)$ (Table 6).

\begin{tabular}{|c|c|c|c|c|c|c|c|}
\hline \multirow{2}{*}{$\begin{array}{l}\text { Sl. } \\
\text { No. }\end{array}$} & \multirow{2}{*}{ Groups } & \multicolumn{2}{|c|}{$\begin{array}{c}\text { Group } \\
\text { L Vs L C }\end{array}$} & \multicolumn{2}{|c|}{$\begin{array}{c}\text { Group } \\
\text { L Vs L D }\end{array}$} & \multicolumn{2}{|c|}{$\begin{array}{l}\text { Group } \\
\text { LC Vs L D }\end{array}$} \\
\hline & & $\begin{array}{c}\text { t- } \\
\text { value }\end{array}$ & $\begin{array}{c}\text { p- } \\
\text { value }\end{array}$ & $\begin{array}{c}\mathrm{t}- \\
\text { value }\end{array}$ & $\begin{array}{c}\text { p- } \\
\text { value }\end{array}$ & $\begin{array}{c}\text { t- } \\
\text { value }\end{array}$ & $\begin{array}{c}\text { p- } \\
\text { value }\end{array}$ \\
\hline 1 & $\begin{array}{c}\text { Time of } \\
\text { Rescue } \\
\text { Analgesia } \\
\text { (in min) }\end{array}$ & 20.98 & $0.00 \$$ & 32.52 & $0.00 \$$ & 9.78 & $0.00 \$$ \\
\hline \multicolumn{8}{|c|}{$\begin{array}{c}\text { Table 6: Showing Intergroup Statistical Comparison of Time For } \\
\text { Rescue Analgesia (Min) Among Three Groups }\end{array}$} \\
\hline
\end{tabular}

\section{HEMODYNAMIC CHANGES}

\section{Pulse Rate}

The mean $( \pm \mathrm{SD})$ of preoperative $\mathrm{PR} / \mathrm{min}$ was $83.43 \pm 5.70$ in Group L, 85.83 \pm 5.72 in Group LC and 88.9 \pm 7.47 in Group LD. In Group L pulse rate significantly decreased up to $60 \mathrm{~min}$ $(p<0.00)$ and thereafter these changes became insignificant ( $p>0.05$ ), while in Group LC and Group LD significant decrease in pulse rate from baseline was observed $(\mathrm{p}<0.05)$. On intergroup analysis, changes in pulse rate between Group $\mathrm{L}$ 
and Group LC and Group L and Group LD were statistically significant $(p<0.05)$, whereas the difference between Group LC and Group LD were statistically insignificant ( $p>0.05$ ).

\section{Systolic Blood Pressure}

SBP fall to below basal value till $60 \mathrm{~min}$. Thereafter SBP started to rise in group $L$ and remain above basal value till the end of study. In Group LC, these values started to rise but remained below baseline till $390 \mathrm{~min}$ and reached to basal value at the end of study period. In Group LD, this fall continued till the end of study period and never regains the basal value till the study period.

On statistical analysis, these changes were significant till 60 min $(p<0.05)$ in all three groups, whereas in group LC and LD changes were significant $(\mathrm{p}<0.05)$ till $330 \mathrm{~min}$.

\section{Diastolic Blood Pressure}

In Group L changes in mean DBP were insignificant from basal value till the end of surgery. In Group LC after an initial fall from basal value up to $150 \mathrm{~min}$ DBP started to rise, but remain below basal value till the end of study period, whereas in Group LD DBP remained below basal value throughout the study period. On statistical analysis, these changes were statistically insignificant in Group L ( $>>0.05)$. In Group LC and LD changes were statistically significant throughout the study period $(\mathrm{p}<0.0 .5)$

\section{Sedation}

In Group L none of the patient had sedation, in Group LC $43.33 \%$ patients had sedation of grade 1 , while in group LD $66.66 \%$ patients had sedation of grade 2 and $23.33 \%$ patients had sedation of grade 1 . Thus it was found that Dexmedetomidine added to Levobupivacaine causes more sedation than clonidine when added to Levobupivacaine

\section{Side Effects}

No complication was found in Group L, while in Group LC 6.66\% and in Group LD 30\% patients had bradycardia and $43.33 \%$ patients in Group LC and 90\% patients in Group LD had sedation (Table 7).

\begin{tabular}{|c|c|c|c|c|c|c|}
\hline \multirow[t]{2}{*}{ Complications } & \multicolumn{2}{|c|}{$\begin{array}{c}\text { Group } \\
\text { L }\end{array}$} & \multicolumn{2}{|c|}{ Group LC } & \multicolumn{2}{|c|}{$\begin{array}{l}\text { Group } \\
\text { LD }\end{array}$} \\
\hline & $\mathbf{n}$ & $\%$ & $\mathbf{n}$ & $\%$ & $\mathbf{N}$ & $\%$ \\
\hline Nausea & - & - & - & - & - & - \\
\hline Vomiting & - & - & - & - & - & - \\
\hline $\begin{array}{l}\text { Respiratory } \\
\text { depression }\end{array}$ & - & - & - & - & - & - \\
\hline Bradycardia & - & - & 2 & 6.66 & 9 & 30 \\
\hline Sedation & - & - & 13 & 43.33 & 27 & 90 \\
\hline
\end{tabular}

\section{DISCUSSION}

We compared dexmedetomidine and clonidine as an adjuvant to levobupivacaine in supraclavicular brachial plexus block and found that there was significantly increased duration of sensory and motor blockade in the dexmedetomidine group than in the clonidine group without any adverse effects.

The onset and duration of sensory blockade was rapid in dexmedetomidine group as compared to clonidine group, but the difference was statistically insignificant $(p>0.05)$. These observations were in accordance with Esmaoglu A, et al.15
Other researchers also confirmed the same results. ${ }^{19,20,21,22,23,24,25,26,27,28,29}$

The time of onset and duration of motor blockade was found to be rapid in dexmedetomidine as compared to clonidine group. These changes were statistically significant when compared to each other $(\mathrm{p}<0.05)$. These findings are in accordance with Chakraborty S, et al. ${ }^{20}$ Duma et al.19, EI Saied AH, et al. ${ }^{29}$ Other studies also had similar results. $20,21,22,23,25,27,28,29$

The time of rescue analgesia as assessed by VAS score was prolonged in Group LD as compared to other Groups (LD>LC $>$ L). On intergroup comparison, these changes were found to be statistically significant.

These findings are supported by EI Saied AH, et al. ${ }^{29}$ who evaluated that addition of clonidine to ropivacaine significantly increased duration of analgesia from $587 \pm 40 \mathrm{~min}$ to $828 \pm 35$ min respectively ( $\mathrm{p}<0.001)$.

Haemodynamic parameters are better stable in dexmedetomidine group.

It was found that Dexmedetomidine when added to Levobupivacaine causes more sedation than clonidine when added to Levobupivacaine.

Esmaoglu A et al. ${ }^{15}$, Swami SS et al. ${ }^{25}$ and Ammar and Mahmoud. ${ }^{30}$ had similar experience.

The analgesic effects of alpha- 2 adrenoceptor agonists could be because of vasoconstriction at injection site, direct suppression of impulse propagation through neurons, local release of enkephalin-like substance, a decrease in localized inflammatory mediators and an increase in anti-inflammatory cytokines through an alpha-2 adrenoceptor-mediated mechanism.

\section{Side Effects}

Bradycardia and sedation is the side effect seen in dexmedetomidine group. Esmaoglu A et al. ${ }^{15}$ also found bradycardia in 7 patients of dexmedetomidine group.

\section{CONCLUSION}

When dexmedetomidine added to Levobupivacaine it fastens the onset of motor blockade, prolongs the duration of sensory and motor blockade as compared to Clonidine. Time for rescue analgesia is more prolonged with dexmedetomidine than clonidine. Dexmedetomidine produces higher degree of sedation as compared to clonidine. Haemodynamic parameters are better stable in dexmedetomidine group.

\section{REFERENCES}

1. Urmey WF. Upper extremity blocks. In: Brown DL, editor. Regional Anaesthesia and Analgesia. Philadelphia: W.B.Saunders, 1996:254-278.

2. Lanz E, Theiss D, Jankovic D. The extent of blockade following various techniques of brachial plexus block. Anesth Analg( jan)1983; 62(1): 55-8.

3. Fischer HBJ. Brachial plexus anaesthesia. In : principles and practice of regional anaesthesia; Wildsmitis JAW, Armitage EN, Mc Clure JH, editors, third edition. London: Churchill Livingstone, 2003: 193-204.

4. De Jong R. Local anesthetic pharmacology. In: Brown DL, ed. Regional Anesthesia and Analgesia. Philadelphia, Pa: Saunders;1996:124-142.

5. Albright GA. Cardiac arrest following regional anesthesia with etidocaine or bupivacaine [editorial]. Anesthesiology. 1979;51:285-287.

Jemds.comOriginal Article 
6. Cox CR, Faccenda KA, Gilhooly C, Bannister J, Scott NB, Morrison LMM. Extradural $S$ (-) bupivacaine: comparison with racemic RS-bupivacaine. Br J Anaesth. 1998;80:289-293.

7. Kopacz D.J., Allen H.W. Accidental intravenous levobupivacaine. Anesth Analg. 1999;89:1027-1029.

8. Popping DM, Elia N, Marret E, Wenk M, Tramer MR. Clonidine as an adjuvant to local anesthestics for peripheral nerve and plexus blocks: a meta-analysis of randomized trials. Anesthesiology. 2009;111:406-415.

9. McCartney CJ, Duggan E, Apatu E. Should we add clonidine to local anesthetic for peripheral nerve blockade? A qualitative systematic review of the literature. Reg Anesth Pain Med 2007; 32:330-8.

10. Kauppila T, Kemppainen P, Tanila H, Pertovaara A. Effect of systemic medetomidine, an alpha2 adrenoreceptor agonist, on experimental pain in humans. Anesthesiology. 1991;74:3-8.

11. Venn RM, Bradshaw CJ, Spencer R, Brealey D, Caudwell E, Naughton C, Vedio A, Singer M, Feneck R, Treacher D, Willatts SM, Grounds RM. Preliminary experience of dexmedetomidine, a novel agent for postoperative sedation in the intensive care unit. Anaesthesia 1999;54:1136-42.

12. Kamibayashi T, Maze M. Clinical uses of a2 adrenergic agonists. Anesthesiology. 2000;93:1345-9.

13. Memis, D, Turan A, Karamanliog lu B, Pamuku Z, Kurt I. Adding dexmedetomidine to lidocaine for intravenous regional anesthesia. Anesth Analg 2004; 98: 835-40. 14.

14. Kanazi GE, Aouad MT, JAbbour- Khoury SL, Al Jazzar $\mathrm{MD}$, Alameddine MM, Al-Yaman R, et al. Effects of low dose Dexmedetomidine or clonidine on characteristics of spinal block. Acta Anaesthesiol Scand.2006;50:2227.

15. Esmaoglu A, Yegenoglu F, Akin A, Turk CY. Dexmedetomidine added to levobupivacaine prolongs axillary brachial plexus block. Anaesth Analg. 2010;111:1548-51.

16. Obayah GM, Refaie A, Aboushanab O, Ibraheem N, Abdelazees M. Addition of dexmedetomidine to Bupivacaine for greater palatine nerve block prolongs postoperative analgesia after cleft palate repair. Eur J Anaesthesiol. 2010;27:280.

17. Peterson Kandall F, Kendall McCreary E,eds Muskeln : Function and tests. New York: Gustav Fischer Verlag Stuwartt 1988; 3-13.

18. Chernik D.A, Gilling D, and Taine H: Validity and reliability of the observer's assessment of alertness/sedation scale: study with intravenous midazalom. J Clin Psychol Pharmacol, 1990; 10:244257
19. Duma A, Urbanek B, Sitzwohl C, Kreiger A, Zimpfer M and Kapral S. Clonidine as an adjuvant to local anaesthetic axillary brachial plexus block: a randomized, controlled study. Br J Anaesth 2005; 94:112-116.

20. Chakraborty S, Chakrabaarti J, Mandal MC, Hazra A, Das S. Effect of clonidine as adjuvant in bupivacaine induced supraclavicular brachial plexus block: A randomized controlled trial. Indian J Pharmacol. 2010; 42:74-77.

21. Patel C, Parikh H, Bhavsar MM, Upadhyay R. Clonidine as adjuvant to $0.75 \%$ ropivacaine in supraclavicular Brachial Plexus Block for postoperative analgesia: A single blind randomized controlled trial. International J Bio Med Res 2014;05(05):327-29.

22. Baj B, Tyagi V, Chaudhri RS, Derashri A. A comparative Study of effect of Clonidine added to Ropivacaine versus Plain Ropivacaine during Supraclavicular Brachial Plexus Block. Journal Of Evolution Of Medical and Dental Science 2013;2(52):10228-35

23. Kaygusuz K, Kol IO, Duger C, Gursoy S, Ozturk H, Kayacan $U$ et al. Effects of adding Dexmedetomidine to Levobupivacaine in Axillary Brachial Plexus Block. Curr Ther Res Clin Exp 2012;73(5):103-11.

24. Gandhi R, Shah A, Patel I. Use of Dexmedetomidine along with Bupivacaine for Brachial Plexus Block. National J Med Res 2012;2(1):67-69.

25. Swami SS, Keniya VM, Ladi SD, Rao R. Comparison of dexmedetomidine and clonidine ( $\alpha 2$ agonist drugs) as an adjuant to local anaesthesia in supraclavicular brachial plexus block: A randomized double blind prospective study. Indian J Anaesth 2012; 56:243-249.

26. Dar FA, Najar MR, Jan N. Dexmedetomidine Added to Ropivacaine prolongs Axillary Brachial Plexus Block. International J Bio Med and Advance Res 2013;04(10):719-22.

27. Agrawal S, Aggarwal R, Gupta P. Dexmedetomidine Prolongs the effect of Bupivacaine in Supraclavicular Brachial Plexus Block. J Anaesthesiol Clin Pharmacol 2014;30(1):36-40.

28. Zhang YU, Wang CS, Shi JH, Sun B, Liu SJ, Li P et al. Perineural administration of Dexmedetomidine in combination with Ropivacaine prolongs Axillary Brachial Plexus Block. Int J Clin Exp Med 2014;7(3):680-85.

29. El Saied AH, Steyn MP, Ansermino JM. Clonidine prolongs the effect of Ropivacaine for Axillary Brachial Plexus Blockade. Can J Anesth 2000;47(10):962-67.

30. Ammar AS, Mahmood KM. Ultrasound guided single injection infraclavicular brachial plexus block using lignocaine alone or administered with dexmedetomidine for pain control in upper limb surgery: A prospective randomized controlled trial. Saudi J Anaesth 2012; 6:109-114. 